\title{
Examination Of Interaction And Statistical Differences Between Information And Communication Within Internal Control And Managers’ Perceived Communication Skills
}

\author{
Ibrahim Yalcin, Assistant Prof. \\ Nigde University, Nigde, Turkey \\ Mustafa Seker, PhD Student \\ Abdullah Gul University, Kayseri, Turkey
}

doi: 10.19044/esj.2016.v12n8p240 URL:http://dx.doi.org/10.19044/esj.2016.v12n8p240

\begin{abstract}
Internal control, which plays a proactive and integral role in organizations' adaptation to changes and alterations that they face, is a dynamic structure that is developed as a result of strategic plans and analyses which contributes greatly to the realizing of organizational strategies. Strategic analysis has two aspects. First one is the aspect that displays the internal characteristics of organization and the second is related to its external environment. Information and communication have vital importance because of being both one of the internal characteristics of organization and one of the compounds of internal control. In the application stage of the research, a face-to-face survey was applied to 373 people selected by simple random sampling, who work at state schools of primary and secondary education in province of Nigde, in Turkey. Hypotheses that were formulated according to research model were analyzed by appropriate statistical methods. Consequently, perceived communication skills of managers are effective on internal control information and communication and there are statistical relationship and significant differences between them.
\end{abstract}

Keywords: Strategic Management, Internal Control, Communication Skills, Information and Communication

\section{Introduction}

Internal control is an important part of an organization and has a great importance in management's assurance. Supplementary factor of internal control is a reliable information system. Internal control contains plans and methods used by management in order to achieve its goals and it contributes 
to management. Internal control is the place where corruptions and cheats are noticed and hindered first. For an efficient internal control structure, environment is prepared and managements, which want to success, determine risks and take precaution. While these regulations are done inside the management, roadmap that ensures information users outside the management is specified and those who are concerned are informed.

Internal control does not provide an absolute assurance but a reasonable assurance. Internal control is not an event but continuous actions that occur throughout the activity (Korkmaz, 2007: 4). Continuity of actions necessitates performing activities along with interactive communication. The communication between organization and its workers is significantly conducted by managers. Feedbacks that managers must give their workers, with whom they create the difference special to organization, in order to take better results from work and ensure the work satisfaction must have some characteristics. Characteristics of feedbacks, which managers give workers while communicating face-to-face, should be appropriate to situation and event, clear, certain and structured, not aimed at the general, should deal with a certain behavior and measuring criterion, not people or intentions of them or their personalities, it should be done efficiently and dually, should aim to support workers instead of criticizing them or finding their deficiencies.

Information and communication are vital for realizing general aims of internal control. Information in every stage of an organization is required for an efficient internal control and realizing organization's aims. Capacity of management for making appropriate decisions is influenced by the quality of information and this information should be appropriate, timely, current, accurate and available.

\section{Communication}

First of all, communication has a host of definitions. To understand the concept, some definitions of it given below.

Communication is the process in which information is produced, transferred and perceived (Caglar, Kilic, 2014: 3). Communication is the transfer of information, data and perception from one person to another (Kocel, 2011: 521). Communication is the transfer of an emotion, sense, meaning, thought and opinion from one individual to another via speaking, listening, writing, actions, behaviors, manners, pictures, markers and signs (Sampton, 1995: 26). Communication is an interaction process involving people's efforts to perceive and answer each other (Guney, 2001: 196). Communication is the use of words and other signs such as certain facial expressions, gestures and physical appearance in order to achieve various goals (Sayers et al, 1993: 9). 
Main purpose of communication is to be effective over environment, change and develop other's behaviors and attitudes (Altintas, Camur, 2001: 2). Communication in regard to managers is the main tool which they use in order to have a task done (Caglar, 2014: 65).

According to research of Mehrabian and Ferris, communication is done with (Yalcinalp, 5-6):

$55 \%$ with body language,

$38 \%$ with tone of voice and

$7 \%$ with used content or words.

Communication is dealt in mainly three categories: nonverbal, verbal and written.

Communication has four functions: control, motivation, emotional expression and information, and all of these have equal importance. Organizations need to have control over their workers in various ways: encourage their workers in good performance, let them express their feelings and create decision options in order to display effective performance (Robbins, Judge, 2012: 342-343).

\section{Basic Features of Effective Communication}

Basic features of an effective communication can be listed as follow (Altintas, Camur, 2001: 3-5):

- $\quad$ First impression is important in communication; communication is not just information exchange, communication process is a whole and communication is done not against a person, rather with a person (Altintas, Camur, 2001: 3-5).

- Communication is not done to someone, done with someone. Communication is different from information. It is an action whereas information is a content. Communication is not repeated. Message is regarded when something is spoken (Cooper, 1989: 15-16).

- It is impossible not to communicate, communication has relation and content phases (erdalerdogdu.com, 2016).

- $\quad$ Communication is a dynamic fact and it depends on certain patterns. It is a product of people's behaviors, conveys information. Healthy people help communication (Caglar, Kilic, 2014: 3-4).

- Communication is a versatile process that continues constantly (Bingaman, 1993: 14).

- Communication is a psychological fact that enables the information, meaning, emotion and thought transaction among social units. It provides interaction. It is the process in which people recognize others and realize their own existences (Ozer, 2009: 96-98).

- Communication is clear, concise and complete (Sampson, 1995: 26). 
- $\quad$ Communication is a psychological fact provides interaction and helps to establish healthy relationships (Guney, 2001: 198).

Consequently, while it impossible to reach perfect communication, there is a positive relation between effective communication and worker's productivity (Robbins, Judge, 2012: 365).

\section{Organizational Communication}

Organizational communication is the communication, which takes place in an organization, is related to organization and done by organization. Organizational communication is the "blood" that animates the organization, an "adhesive" that holds organization together, a "tie" that links system and a "power" that expands all over the organization (Gulnar, 2007: 43). Organizational communication is a social process that enables the continuous transfer of information and thoughts between both various parts and elements that constitute the organization and its environment (Caglar, 2014: 63). This process requires creating horizontal and vertical channels that provide the transfer of information, data and perceptions among all units that constitute the organization (Simsek, Akgemci, Celik, 2011: 159).

Functions of organizational communication can be sorted as giving information, regulating, integrating, managing, persuading, socializing, contributing to team spirit and improving quality (Gulnar, 2007: 44-51).

\section{Purposes of Organizational Communication}

Main purposes of organizational communication that also affect outside the organization are listed below (Caglar, 2014: 65):

- $\quad$ To improve motivation inside organization, build good relationships between workers, increase work satisfaction of workers, contribute to development of management and workers by regulating the relationships between them and provide coordination inside institution (Dundar, Ozel, 2012: 106),

- To make workers be aware of organization's mission, vision, purposes, aims and policies,

- $\quad$ To give information related to job and processes and ease the job and skill education by this way,

- To give information about social and economic problems of organization and enlighten workers about emotional and conflicting issues inside the organization,

- To encourage innovation and creativity,

- $\quad$ To enlighten concerned sides about organization's activities,

- $\quad$ To increase the level of participation in organizational life,

- $\quad$ To encourage dual communication between managers and workers, 
- $\quad$ To inform workers about advancement in work and improve workers' qualities of representing the organization,

- $\quad$ To try to create an organizational climate, culture and identity and maintain it,

- $\quad$ To increase motivation inside the organization,

- $\quad$ To make a contribution to cooperation between organizations.

- $\quad$ It helps people overcome the needs or problems that they cannot do on their own by demanding others' assistance (Tengilimoglu, Ozturk, 2011: $55)$.

\section{Characteristics of Managers With Communication Skills}

Effective communication directly affects managers' successes in business. A large portion of the formal and unofficial education that a manager has taken is related to communication. Managers can manage how they give task to workers, evaluate workers' performance, debate, impose discipline, educate, interview and motivate by good communication skills (Sayers et al, 1993: 8-9).

Thus, we can list communication skills that managers must have as below:

- $\quad$ They should try to create environments in which related people can understand their messages before they start communication (Sayers et al, 1993: 8-9).

- $\quad$ They should have sufficient technical information and experience about communication.

- $\quad$ They should follow the changes and advancements closely by analyzing their environments continuously and with a strategic point of view.

- $\quad$ They should be a writer, speaker and listener who use time properly and master the subject matter (Williams, 1991: 13-17).

- $\quad$ They should contribute to the development of their workers by communicating with them in a friendly way and in a motivating manner, establish humane relationships and help workers discover their expectation (Beduk, 166-168, dergipark.ulakbim.gov.tr, 2016).

- $\quad$ They should establish a great feedback order (Sabuncuoglu, 2010: 57; Barli, 2010: 319).

- $\quad$ They should inform workers about working order, strategies, policies, aims, objectives and career objectives of the management (Gulluoglu, 2011: 24).

- $\quad$ They should have the talent to empathize (Sabuncuoglu, 2010: 56).

- $\quad$ They should relieve people by removing distractions in communication process (Barli, 2010: 322). 
- $\quad$ They should establish a connective and coordination-providing communication order by providing continuity of information flow. They should communicate imperatively and instructively when it is necessary (Gulluoglu, 2011: 24-26).

- They should adopt we-centered communication and possess the ability to empathize (Simsek, Akgemci, Celik, 2011: 172).

- They should care about the importance of first impression in communication and recognize the mass that they communicate with. They should have the ability to use body language effectively. They should take professional assistance on this subject.

- $\quad$ They should be known by everyone, be wise, avoid unnecessary information and details and behave appropriately to their position and roles (Erdogan, 282-283).

- $\quad$ They should use communication tools, technologies and channels effectively (Ozer, 2009: 113).

- $\quad$ They should not use a harsh, nervous, aggressive, imperative, faultfinder, sarcastic, threatening and prejudiced language, on the contrary, they should be patient (Barli, 2010: 222).

- $\quad$ They should have ability to communicate both inside and outside the organization effectively. They should use a plain and clear language in their communications (Sabuncuoglu, 2010: 51-52).

- They should follow the process and results of communication, manage communication course well, empathize, use a plain language, increase communication channels and use present information technologies well (Kocel, 2011, 542-543).

\section{Internal Control}

Internal control is not a main objective, rather, a tool for achieving goals, it has a dynamic structure and it provides reasonable assurance, cannot guarantee accuracy of information (Akisik, 2005: 91).

Internal control is a management control built as a part of the basis for managers to operate the institution and realize the aims on the basis of continuity (Korkmaz, 2007: 8) and it is an activity done by management in order to increase the chance of aims, which are determined before, to be achieved (Sawyer et al, 2003: 64).

The Ministry of Finance of Republic of Turkey, which is assigned central harmonization related to internal control system in public finance management, is authorized to take necessary precautions related to this subject all over the country. In addition, apart form the internal control system, Primary Financial Control and Internal Control System is regulated as a supplementary factor (Akyel, Soyler, 2010: 1011). It is stated in the law 
that financial management and internal control of public administrations comprise expense units, accounting and financial services, primary financial control and internal control; requirements for a sufficient and efficient control system are sorted (Colak, 2008: 265).

\section{Purposes of Internal Control}

Aims that managements hope to achieve when a good internal control structure is built and managed are mainly separated into five groups below (Guredin, 2000: 169):

- $\quad$ Providing reliable information,

- $\quad$ Increasing the productivity of management activities,

- $\quad$ Appropriateness to laws and regulations,

- $\quad$ Protecting management properties and resources,

- $\quad$ Ensuring that management achieve its goals and aims.

\section{Components of Internal Control}

According to model that was developed by COSO and published in 1992, internal control system consists of five components (Simmons, 1997: 38):

$\begin{array}{ll}\text { - } & \text { Control environment } \\ \text { - } & \text { Risk Assessment } \\ \text { - } & \text { Information and Communication } \\ \text { - } & \text { Monitoring }\end{array}$

\section{Control Environment}

Control environment forms the basis of internal control by providing internal control discipline as well as creating the atmosphere affecting the general quality of internal control. Control environment has a general effect on which strategy and what kind of aims are determined and it structures control activities (Akyel, 2010: 86). Besides, a management's perspective on importance and quality of the control inside the organization expresses its attitudes and behaviors as well as providing necessary order and atmosphere in order to achieve aims of internal control. Thus, control awareness in organization constitutes the base of control environment (Candan, 2006: 12).

\section{Risk Assessment}

Risk assessment appropriate to work ethic should enable to manage and appreciate. Top management should notice the risks that can affect the institution in activity periods and take precautions. Therefore, internal 
control structure must identify the risks that management may face, take precautions against existing or possible risks (Alagoz, 2008: 103).

Risk assessment is to identify possible mistakes, reveal these mistakes and make control policies and procedures to avoid them. Risk assessment in managements contains identifying, analyzing and managing the risks affecting the aims of managements, not auditor's ordinary assessment of control risks in case there are mistakes in financial tables (Doyrangol, 2001: 51-52).

\section{Control Activities}

Control activities are precautions taken by management in order to achieve objectives. This component of internal control is regulated to neutralize the risks that management may face (Akbulut, 2012: 179). It is difficult to make a common list because there might be changes in control activities from one management to another. However, examinations done by management, management of human capital, controls on information system, physical controls on sensitive creatures, examination of performance, creating and reviewing performance criteria and indications, separating duties, fulfilling operations and works properly, recording operations and works completely and promptly, restricting access to the resources and records and putting operations and internal control in writing properly can be examples of control activities (Uyar, 2010: 49).

\section{Information and Communication}

Information is required for achieving goals in an efficient internal control structure in all departments of an institution. Information flow inside management is provided by data processing. In internal control structure, information should be recorded, grouped and announced immediately. Appropriateness, accuracy and availability of information ensure its reliability. This system should be regulated in such a way that it contains everybody from workers at lowest level to the top management (Uzay, 1999: 32).

Information and communication are vital for realizing general aims of internal control. Information in every stage of an organization is required for an efficient internal control and realizing organization's aims. Capacity of management for making appropriate decisions is influenced by the quality of information and this information should be appropriate, timely, current, accurate and available (Akyel, 2010: 88).

\section{Monitoring}

Depending on different institutions and personnel, it is to determine whether internal controls are maintained appropriately to the policies and 
procedures that have been settled previously and these assessments put the institution in new risks. Monitoring, based on a time basis, consists of the assessment of quality of internal control, design and operation of controls and attitudes, precautions that must be taken (Demirbas, 2005: 172). Monitoring of activities in internal control structure means interpretation and assessment. Aim of monitoring is to continue and improve internal control (Aksoy, 2008: 19).

\section{Some Academic Studies Related to Internal Control in Turkey}

Demirbas (2005) researched the changes that occur in the scope of internal control and its activities based on internal control; Dabbagoglu (2009) researched internal control in regards to accounting and ERP system; Akyel (2010) researched general concept, factors and activities of internal control in Turkey; Omerbek and Altay (2011) researched the activity of internal control in the departments of store, purchase, front office, accounting and management in tourism sector; Turedi (2012) researched relations between internal control system and total quality management; Okten and Kargin (2012) researched credit control and recognition process in the scope of internal control activities in banking; Ibis and Catikkas (2012) researched internal control structuring in Turkey within public enterprises; Topcu (2013) researched a structure, based on a system that is structured around a branch formed by fiscal service units, that involves all personnel from the lowest level to the top management and enables to share real time data, risk control and regulatory responses and the level of settlement of internal control system in provinces though settlement in the center progresses, by two case analysis method. As it can be perceived from the examples above, studies aimed at internal control in Turkey especially in public subjects are mainly aimed at financial issues rather than system installation issues. Our research differs from other studies in that it examines the topics of information and communication which are from the aspect of managers' communication skills and the components of internal control.

\section{Method}

\section{Purpose of Research}

It was aimed to examine the interaction between managers' communication skills and information and communication standard of internal control.

\section{Extent and Method of Research}

This research was done in order to examine the interaction between managers' communication skills and information and communication standard of internal control. Relational screening model was applied. 
Workers at primary and secondary schools of The Ministry of National Education in Nigde province constitute the population of the research. Sample of the research consists of 373 people, 164 (44\%) women and 209 (56\%) men, chosen by simple random sampling.

\section{Measuring Tools and Applied Analyses}

Measuring tools below constitute the research form:

1- Demographic data form: It is formed by 5 questions such as age, gender, educational status, assignment and total work experience.

2- Manager's communication skills scale: It is 17-question scale developed by Haluk Tanriverdi, Orhan Adiguzel and Munire Ciftci (2010). Questions are scaled in 7 point likert type. It comprises of 3 subscales, satisfaction of communication with manager, manager's communication proficiency, message level and perception. Cronbach's Alpha level of scale is 0.861 .

3- Internal control information and communication scale: It is formed by 3 questions based on internal control standards. As a result of the factor analysis, it was determined that there is factorability as one factor and total variance is at the level of 0.528 .

In the research, reliability of managers' communication skills scale was determined by internal consistency method. Alpha coefficient is the most common method used for testing the reliability of scales. Alpha coefficient gets a number between zero and one. Reliability of the scale in the research must have an alpha coefficient level of 0.70 to be valid (Hair et al, 1998: 118).

Factor analysis was done in order to determine the factorability level of internal control information and communication questions and the level of explaining the statement to be measure. Factor analysis creates factors related to the structure or concept to be measured. According to analysis results, items are removed from tool, analysis is repeated. If it is required to add new items to the tool, items are added, data is gathered again and analysis is repeated. This process continues until researcher reaches an appropriate solution that contains enough items to measure the issue. In this process, factor analysis searches for answers to the questions: "Do scores gathered from this test measure the thing that is considered to be solved by the test?" Thus, factor analysis significantly contributes to the evaluation of structural reliability of test/scale scores (Buyukozturk, 2002: 433-470).

Correlation test was done in order to determine the relationship between internal control information and communication and managers' communication skills. Correlation coefficient is a value that measures the degree of the linear relation between two variables and it changes between -1 and +1 . r's being close to -1 indicates that there is a very strong negative 
linear relation between these variables and its being close to +1 does that there is a very strong positive linear relation between them (Altunisik, Coskun, Bayraktaroglu, Yildirim, 2010: 227).

In addition to the analyses cited above, there are also frequency, percentage, arithmetic mean, standard deviation, one-way anova, tamhane test and regression analyses in the research.

\section{Hypotheses of Research} research:

Hypotheses below were developed appropriately to the purpose of the

H1: Managers’ communication skills have effects on internal control information and communication.

H2: There is correlation between managers' communication skills and internal control information and communication.

H3: There is statistical significance between manager's communication skills and internal control information and communication.

\section{Findings of the Research}

Descriptive statistics related to demographic data of participants are given in Table-1.

Table-1: Descriptive Statistics of Demographic Data

\begin{tabular}{|c|c|c|c|c|c|}
\hline Age & Frequency & Percentage & Experience & Frequency & Percentage \\
\hline Age 18-30 & 56 & 15,0 & $0-10$ years & 87 & 23,3 \\
\hline Age $31-40$ & 159 & 42,6 & 11-20 years & 167 & 44,8 \\
\hline Age $41-50$ & 134 & 35,9 & 21-30 years & 99 & 26,5 \\
\hline Age 51 and older & 24 & 6,4 & $\begin{array}{l}31 \text { years or } \\
\text { more }\end{array}$ & 20 & 5,4 \\
\hline Total & 373 & 100,0 & Total & 373 & 100,0 \\
\hline Job & Frequency & Percentage & Gender & Frequency & Percentage \\
\hline Pre-school Teacher & 40 & 10,7 & Woman & 164 & 44,0 \\
\hline Form Teacher & 100 & 26,8 & Man & 209 & 56,0 \\
\hline Certified Teacher & 171 & 45,8 & Total & 373 & 100,0 \\
\hline $\begin{array}{c}\text { Administrative } \\
\text { Personnel/Technical } \\
\text { Staff }\end{array}$ & 22 & 5,9 & $\begin{array}{c}\text { Educational } \\
\text { Field }\end{array}$ & Frequency & Percentage \\
\hline Manager & 40 & 10,7 & $\begin{array}{c}\text { Social } \\
\text { Sciences }\end{array}$ & 179 & 24,7 \\
\hline \multirow[t]{3}{*}{ Total } & 373 & 100,0 & Sciences & 102 & 27,3 \\
\hline & & & $\begin{array}{l}\text { Turkish- } \\
\text { Math. }\end{array}$ & 92 & 48,0 \\
\hline & & & Total & 373 & 100,0 \\
\hline
\end{tabular}

When Table 1 above is examined, it can be seen that $44 \%$ of participants are women, $56 \%$ of are men, average of age is 40 or younger 
with such a ratio as $57.6 \%(42.6 \%+15.0 \%)$, average experience in workplace is $11-20$ years with a ratio of $44.8 \%$.

Table-2: Results of Average, Standard Deviation, Variance Values and Factor Analysis

Related to Questions of Standards of Internal Control Information and Communication

\begin{tabular}{|c|c|c|c|c|c|}
\hline Questions & Average & $\begin{array}{c}\text { Standard } \\
\text { Deviation }\end{array}$ & Variance & $\begin{array}{c}\text { Factor } \\
\text { Load }\end{array}$ & $\begin{array}{c}\text { Total } \\
\text { Factor } \\
\text { Variance }\end{array}$ \\
\hline $\begin{array}{c}\text { Report methods of mistakes, } \\
\text { irregularity and corruption are } \\
\text { defined and announced. }\end{array}$ & 4,47 & 1,72 & 2,96 & 0,76 & \\
\hline $\begin{array}{c}\text { Managers do not investigate } \\
\text { reported mistakes, irregularity } \\
\text { and corruption sufficiently. }\end{array}$ & 3,32 & 1,63 & 2,67 & 0,78 & \multirow{2}{*}{$\% 52,82$} \\
\hline $\begin{array}{c}\text { Personnel who report mistakes, } \\
\text { irregularity and corruption are } \\
\text { not treated unfairly and } \\
\text { discriminatively. }\end{array}$ & 3,82 & 1,93 & 3,71 & 0,64 & \\
\hline
\end{tabular}

When the answers to the questions of standards internal control information and communication are analyzed, second question has the lowest values with 3.32 while first question has the highest value with 4.47 . When it is looked at standard deviation, which is average central inclination measure and variance which is square of standard deviation, third question has the highest standard deviation with 1.93 and thus it has the highest variance value with 3.71. Second question has the lowest standard deviation with 1.63 and it also has the lowest variance value with 2.67 . When it is looked at average, standard deviation and variance values of questions of internal control information and communication, it can be seen that participants answer as rarely, sometimes and often.

Table-3: Regression Analysis to Determine the Effects of Managers' Communication Skills on Internal Control Information and Communication

\begin{tabular}{|l|l|l|l|l|l|l|l|l|}
\hline Variables & $\mathbf{B}$ & $\mathbf{t}$ & Sig. & $\mathbf{R}$ & $\mathbf{R}^{\mathbf{2}}$ & $\mathbf{F}$ & Sig.F & Result \\
\hline Constant & 2,330 & 6,434 &, 000 & & & & & \\
\hline $\begin{array}{l}\text { Managers' } \\
\begin{array}{l}\text { communication } \\
\text { skills }\end{array}\end{array}$ &, 339 & 4,334 & & & & & & Assent \\
\hline \multicolumn{7}{|l|}{} \\
\hline $\begin{array}{l}\text { Regression Model Y1 } \\
\text { skills) }\end{array}$
\end{tabular}

One of the main reasons for regression analysis is to predict about future. This requires that mathematical regression model is statistical significant. When table 3 above is analyzed, it can be seen that managers' communication skills have effects on internal control information and communication and the regression formula indicating this effect is 
Y1 $1_{\text {(internal control information and communication) }}=2,33+0,339_{\text {(managers' communication }}$ skills).

Therefore, H1 hypothesis that involves the statement "Managers' communication skills have effects on internal control information and communication" is accepted.

Effects on internal control information and communication, which is a subscale of the scale managers' communication skills, is examined in the table 4 below.

Table-4: Regression Analysis to Determine the Effects of Subscales of Managers'

Communication Skills on Internal Control Information and Communication

\begin{tabular}{|c|c|c|c|c|c|c|c|}
\hline Variables & B & $\mathbf{t}$ & Sig. & $\mathbf{R}$ & $\overline{\mathbf{R}^{2}}$ & $\mathbf{F}$ & Sig.F \\
\hline Constant & 2,450 & 6,672 & ,000 & & & & \\
\hline $\begin{array}{c}\text { Satisfaction of } \\
\text { communication with } \\
\text { manager } \\
\end{array}$ &,- 111 & $-1,432$ & 153 & & & & \\
\hline $\begin{array}{c}\text { Managers' communication } \\
\text { talent }\end{array}$ & 137 & 2,411 & ,016 & & & & \\
\hline $\begin{array}{l}\text { Massage level and } \\
\text { perception }\end{array}$ & ,392 & 9,112 & ,000 & & & & \\
\hline & & & & ,461 & ,213 & 33,216 & ,000 \\
\hline
\end{tabular}

When Table 4 above is examined, it is seen that "satisfaction of communication with manager", which is a subscale of managers' communication skills, has no effect on internal control information and communication ( $\mathrm{p}=0.153$ and $\mathrm{p}>0.05)$; however, "managers' communication talent" $(\mathrm{p}=0.016$ and $\mathrm{p}<0.05)$ and "message level and perception" $(\mathrm{p}=0.000$ and $\mathrm{p}<0.05$ ) subscales have effect on it and regression formula indicating this effect is

Y $2_{\text {(internal control information and communication) }}=2,45+0,137_{\text {(managers' communication talent) }}{ }^{+}$ ,392 (message level and perception).

Table-5: Correlation Test Examining the Relation between Managers' Communication Skills and Internal Control Information and Communication

\begin{tabular}{|l|l|l|}
\hline \multicolumn{2}{|c|}{} & $\begin{array}{l}\text { Internal control information } \\
\text { and communication }\end{array}$ \\
\hline \multirow{2}{*}{ Manager's communication skills } & Pearson Correlation &, $220^{* *}$ \\
\cline { 2 - 3 } & Sig. (2-tailed) &, 000 \\
\hline
\end{tabular}

When table 5 is examined in the light of this information, $r$ value is lower than 0.250 , has a very weak relation. There is a positive, dual and weak relation between managers' communication skills and internal control information and communication at the level of $0.220 * *$. Therefore, H2 hypothesis that involves the statement "There is correlation between 
managers' communication skills and internal control information and communication" is accepted.

Table-6: One-way Anova Test Examining Statistical Significance between Managers’

Communication Skills and Internal Control Information and Communication

\begin{tabular}{ccccccc}
\hline Aspect & $\begin{array}{c}\text { Managers' } \\
\text { communication skills }\end{array}$ & $\mathbf{N}$ & $\mathbf{X}$ & Std. Err. & $\mathbf{F}$ & $\mathbf{p}$ \\
\hline Internal control & Insufficient level & 33 & 4,12 & 0,221 & 11,140 & 0,000 \\
information and & Normal level & 238 & 4,05 & 0,081 & & \\
communication & Good level & 102 & 4,75 & 0,120 & & \\
\hline
\end{tabular}

${ }^{*} \mathrm{p}<.05$

When the results of analysis related to the level of internal control information and communication according to managers' communication skills are examined, there are statistical significance $(p=0.000)$ between internal control information and communication and different categories of managers' communication skills (table 6).

Significance analysis was done in order to determine from which categories managers' communication skills stem. There are findings of Tamhane test in order to determine from which categories of internal control information and communication managers' communication skills stem.

When internal control information and communication according to managers' communication skills is examined according to proficiency level of communication, it has been determined that there is statistical significance between good level and insufficient level at the level of $p=0.048$ and between good level and normal level at level of $p=0.000$ in table 7 .

Table 7: Tamhane test Results Related to from which Group the Differentiation between Internal Control Information and Communication According to Managers' Communication Skills

\begin{tabular}{cccccc}
\hline \multirow{2}{*}{ Aspect } & $\begin{array}{c}\text { (I) Managers' } \\
\text { Communication } \\
\text { Skills }\end{array}$ & $\begin{array}{c}\text { Communication } \\
\text { Skills }\end{array}$ & $\begin{array}{c}\text { (I-J) } \\
\text { Mean } \\
\text { Difference }\end{array}$ & $\begin{array}{c}\text { Std. } \\
\text { Error }\end{array}$ & p. \\
& \multirow{2}{*}{ Insufficient level } & Normal level &, 067 &, 235 &, 989 \\
\cline { 3 - 6 } & & Good level &,$- 624^{*}$ &, 252 &, 048 \\
\cline { 3 - 6 } $\begin{array}{c}\text { Internal control } \\
\text { information } \\
\text { and }\end{array}$ & \multirow{2}{*}{ Normal level } & Insufficient level &,- 067 &, 235 &, 989 \\
\cline { 3 - 6 } communication & & Good level &,$- 690^{*}$ &, 145 &, 000 \\
\cline { 2 - 6 } & \multirow{2}{*}{ Good level } & Insufficient level &, $624^{*}$ &, 252 &, 048 \\
& & Normal level &, $690^{*}$ &, 145 &, 000 \\
\hline
\end{tabular}

*. The mean difference is significant at the 0.05 level.

Therefore, H3 hypothesis that involves the statement "There is statistical significance between manager's communication skills and internal control information and communication" is accepted. 


\section{Results and Recommendations}

In our research, it was determined that managers' communication skills have effects on internal control information and communication and this effect is $\mathrm{Y} 1_{\text {(internal control information and communication) }}=2,33+0,339_{\text {(managers' }}$, communication skills); there is a positive, dual and weak relation between these variables at the level of $0.220 * *$; there is statistical significance between good level and insufficient level at the level of $\mathrm{p}=0.048$ and between good level and normal level at level of $p=0.000$ when it is examined according to proficiency level of communication. In the literature review in research, our research could not be compared to similar studies due to the fact that any academic studies in Turkey that include quantitative measurement and detection directly related to internal control standards.

However, according to results of our research, it was determined that "satisfaction of communication with manager", which is a subscale of managers' communication skills, has no effect on internal control information and communication $(\mathrm{p}=0.153$ and $\mathrm{p}>0.05)$; however, the subscales "managers' communication talent" $(p=0.016$ and $p<0.05)$ and "message level and perception" ( $p=0.000$ and $p<0.05)$ have effects on it.

Presence of management and personnel in internal control, which is the set of rules and regulations related to execution of activities for which organizational managers are responsible, is an inevitable must. Responsibility in internal control contains all tasks in operation process. All managers and workers in an activity process of the organization have roles and responsibilities in common (Aksoy, 2008: 9). Managers must control and check the process while discharging the management function. Convenience or quality of activities along with their appropriateness to internal control should not be ignored.

In Turkey, internal control operation is regulated in general based on only financial factors in the scope of public financial management. Since there are not any general regulations about internal control management related to other activity fields of public management, effectiveness of internal control activities of organizations can be superficial. In public management field, internal control needs to be regulated to contain all activity fields.

Internal control should be designed as a factor that is built integrated to the structure of organization and undertakes the supplementary function of concerned processes as a part of basic management processes. Therefore, when internal control mechanisms are developed appropriately to the organizational strategies, new and different process model need to be created by analyzing organizations with different tools. In this regard, our research is important for both being a technical study analyzing internal control and risk 
management perception and an administrative process management study contributing to organization in realizing its strategic aims.

\section{References:}

Akbulut, E., Isletmelerde Ic Kontrol Sisteminin Etkinliginin Incelenmesi, Electronic Journal of Vocational Colleges. May1s 2012.174-186, 2012

Akisik, O., Ic Kontrol Sistemi ve Bagimsiz Denetimi Icindeki Yeri, Muhasebe ve Denetime Bakış, 4(14), 89-101, 2005

Aksoy, M., Kamuda İç Kontrol ve İç Denetim, Muhasebat Konrolörleri Derneği, Yayin No: 26. Ankara, 2008

Akyel, R., \& Soyler, İ., Yonetimin Kontrol Fonksiyonu Baglamında Kamu Harcamalarinın Kontrolu,Vergi Sorunlari Dergisi. Sayı 258.Mart.7- 20, 2010

Akyel, R., Turkiye'de Ic Kontrol Kavrami, Unsurlari ve Etkinliginin Degerlendirilmesi, Yonetim ve Ekonomi.17(1).83-97, 2010

Alagoz, A.,"Isletmelerde Ic Kontrol Sisteminin Onemi ve Denetim Komiteleri Ile Ic Denetim Birimi Iliskisinin Hata ve Hilelerin Onlenmesindeki Rolu”, Editorler: Dogan Zeki, Inal Mehmet Emin, Tablet Yayinlari, (95-126)Konya, Subat-2008

Altintas, Ersin, Camur, Devrim, Sozsuz Iletisim ve Beden Dili, Nobel Yayinlari No: 331, Ankara, 2001

Altunisik, R., \& Coskun, R., \& Bayraktaroglu, S., \& Yildirim, E., Sosyal Bilimlerde Arastirma Yontemleri SPSS Uygulamali (6.Bask1). Sakarya Yayincilik, 2010

Barli, Onder., Davranis Bilimleri ve Orgutsel Davranis, Aktif, 4. Baski, Erzurum, 2010

Bingaman, Cristine., E., Etkili Sunus, Cev: Erhan TUSKAN, Rota Yayinlari No: 7, 1. Baski, Istanbul, 1993

Buyukozturk, S., Faktor Analizi: Temel Kavramlar ve Olcek Gelistirmede Kullanimi. Egitim Yonetimi Dergisi, Guz, 470-433, 2002

Candan, Ekrem., “Kamu Idarelerinde Ic Kontrol Sistemi ve Sureclerinin Tasarlanmasi, Uygulanmasi ve Gelistirilmesinde Uyulacak Usul ve Esaslar”, Mali Yonetim ve Denetim Dergisi, Sayi: 38, 1- 23, 2006

Cooper, Ken., Sozsuz Iletisim, Cev: Tunc YALKI, Rota Yayinlari, İstanbul, 1989

Caglar, Irfan, \& Kilic, Sabiha., Iletisim Kavrami ve Cesitleri, Genel, Teknik ve Etkili Iletisim, Editorler: Irfan CAGLAR, Sabiha KILIC, Nobel Yayinlari No: 995-036, 1. Baski, Ankara, 2014

Caglar, Irfan., Orgutsel Iletisim Sureci, Genel, Teknik ve Etkili Iletisim, Editorler: Irfan CAGLAR, Sabiha KILIC, Nobel Yayinlari No: 995-036, 1. Baski, Ankara, 2014 
Colak, Bayram., Konu Anlatimli 5018 Sayili Kamu Mali Yonetimi Ve Kontrol Kanunu, Umit Ofset Baski, Ankara, 2008

Dabbagoglu, Kadir., Ic Kontrol Sistemi, Journal of Qafqaz University, Sayi 26, 109-115, 2009

Demirbas, Mahmut., “Ic Kontrol ve Ic Denetim Faaliyetlerinin Kapsaminda Meydana Gelen Degisimler”, Istanbul Ticaret Universitesi Sosyal Bilimler Dergisi Y1l:4 Sayi:7 Bahar 2005/1, 167-18, 2005

Demirbas, Mahmut., “Turkiye’de Denetim Komitesi Uyelerinin Bagimsizliginin ve Etkinliginin Halka Acık Anonim Sirketlerde Tespit Edilmesi”, Modav Muhasebe Bilim Dunyasi Dergisi, Cilt:8, Sayi: Eylul 3, s, 105-132 Ankara, 2006

Doyrangol, Nuran, Comert, Sermaye Piyasasi Araci Kuramlarinda Etkili Bir Ic Kontrol Sistemi ve Ic Denetim Fonksiyonu, Lebib Yalkin Matbaasi, Istanbul, 2001

Dundar, Pelin I., \& Ozel, Elif Koralp., The Effect Of Internal Communication To Quality: A Research Designed For Examining The Effect Of New Communication Technologies To The Quality Of Internal Communication, ODU Sosyal Bilimler Enstitusu Sosyal Bilimler Arastırmaları Dergisi, Cilt: 3 Sayı: 6 Aralık 2012

Erdogan., İlhan, Isletmelerde Davranis, Beta Yayinlari No: 498-49, İstanbul, 1994

Gulluoglu, Ozlem., Orgutsel Iletisim, Iletisim Doyumu ve Kurumsal Baglilik, Egitim akademi, Konya, 2011

Gulnar, Aykut., Orgutlerde Iletisim ve Is Doyumu, Literatur Yayinlari No: 3, Istanbul, 2007

Guney, Salih., Bireylerarasi Iletisim, Editor: Salih GUNEY, Yonetim ve Organizasyon, Nobel Yayınlari No: 265, Ankara, 2001

Guredin, Ersin, Denetim, Beta Basim Yayim Dagitim, 10. Baski, s.168- 169, Istanbul, 2000

Hair, J., Anderson, R., \& Tatham, R., Black, W., Multivariate Data Analysis with Readings, Fifth Edition, Prentice-Hall International Inc, 1998

http://dergipark.ulakbim.gov.tr/selcuksbmyd/article/viewFile/5000084374/50 00078469, BEDUK, Aykut, 24.02.2016, 20: 23

Ibis Cemal., \& Catikkas Ozgur, Isletmelerde Ic Konrol Sistemine Genel Bakis, Sayistay Dergisi, Say1:85/ Nisan-Haziran 2012, 95-121, 2012

Kocel, Tamer., Isletme Yoneticiligi, Beta Yayinlari, 13.Baski, Yayin No: 2551, Isletme-Ekonomi Dizisi: 521, Istanbul, 2011

Korkmaz, Umut, “Kamuda Ic Denetim (1)”, Butce Dunyasi Dergisi, Cilt 2, Sayi 25, Bahar, s. 4- 15, Ankara, 2007

Robbins, Stephen P., \& Judge, Timothy A., Orgutsel Davranis, Ceviren: Azmi YALCIN, Ceviri Editoru: Inci ERDEM, Nobel Yayinlari No: 240-18, Ankara, 2012 
Sampson, Eleri., Imaj Faktoru, Cev: Hakan ILGUN, Rota Yayinlari No: 6, Istanbul, 1995

Okten, Sezayive., \& Kargin Sibel., “Bankacilikta Ic Kontrol Faaliyetleri Kapsaminda Krediler Kontrolu ve Muhasebelestirme Sureci”, Afyon Kocatepe Universitesi, IIBF Dergisi (C.XIV, S II, 2012), 119-136, 2012 Omurbek,Vesile., \& Altay, Sevgi Ozge, “Turizm Isletmelerinde Ic Kontrol Sisteminin Etkinliginin Incelenmesi”, Suleyman Demirel Universitesi Iktisadi ve Idari Bilimler Fakultesi Dergisi, Y.2011, C.16, S.1 s.379-402, 2011

Ozer, M. Akif., Halkla Iliskiler Dersleri, Adalet Yayinevi, Ankara, 2009

Sabuncuoglu, Zeyyat., Isletmelerde Halkla Iliskiler, Alfa Aktuel, 10. Baski, Bursa, 2010

Sayers, Fran., \& Bingaman, Cristine, E., \& Graham, Ralph, Wheleeler, Mardy., Yoneticilikte Iletisim, Cev: Dogan Sahiner, Rota Yayinlari No: 6, Istanbul, 1993

Sawyer L. B., \& Mortimer A.D., \& Scheiner, J.H., \& Graham, A., Sawyer’s Internal Auditing: The Practice of Modern Internal Auditing. The Institute of Internal Auditors, 2003

Simmons, R., Mark., COSO Based Auditing, The Internal Auditor, Altamonte Springs, December, 1997

Simsek, Serif., \& Akgemci, Tahir., \& Celik, Adnan., Davranis Bilimlerine Giris ve Orgutlerde Davranis, 7.Baski, Gazi Kitabevi, Ankara, 2011

Tengilımoglu, Dilaver., \& Ozturk., Yüksel, Isletmelerde Halkla Iliskiler, Seckin Yayınlari, 3. Baski, Ankara, 2011

Topcu, M. Kemal., "Kamuda Ic Kontrol Sisteminin Coso Modeli Baglamında Tasrada Uygulanabilirligi: Ihalelerde Uygulanmasina Yonelik Iki Vaka Analizi”, Sayıstay Dergisi, Sayi: 91/Ekim-Aralik 2013, 5-31, 2013

Turedi, Selda., "Ic Kontrol Sistemi ve Toplam Kalite Yonetimi Iliskisi”, Uluslararasi Alanya Isletme Fakultesi Dergisi, 4(1): 27-37, 2012

Uyar, Suleyman., "UFRS Uygulamalarinda Ic Kontrol Sisteminin Etkisi ve Onemi”, Akdeniz Universitesi Alanya Isletme Fakultesi Dergisi, S:2, S.3760, 2010

Uzay, Saban., Isletmelerde Ic Kontrol Sistemini Incelemenin Bagimsiz Dis Denetim Karar Surecindeki Yeri ve Turkiye'deki Denetim Firmalarina Yonelik Bir Arastirma, Ankara: Sermaye Piyasası Kurulu Yayinlari No: 132, 1999

Willıams, Eggland., Orgutlerde Iletisim, A.U. Yayinlari No: 628, Eskisehir, 1991

Yalcinalp.,Serpil.,moodle.baskent.edu.tr/mod/resource/view.php?id=33\&redi rect=1, 23.02.2016, 23: 20 